\title{
Equilibrium, kinetics and thermodynamic studies of cadmium(II) biosorption on Nannochloropsis oculata
}

\author{
Jyothi Kaparapu ${ }^{1}$ (D) M. Krishna Prasad ${ }^{2}$
}

Received: 7 November 2017 / Accepted: 11 September 2018 / Published online: 25 September 2018

(c) The Author(s) 2018

\begin{abstract}
The marine microalga Nannochloropsis oculata was investigated for its biosorption capacity for the removal of Cd(II) ions from aqueous solution using batch mode experiments. $\mathrm{pH}(2-5)$, biomass dosage $(0.0191 \mathrm{~g} / 50 \mathrm{~mL}$ and $0.392 \mathrm{~g} / 50 \mathrm{~mL})$ and temperature (293-323 K) being the experimental parameters affecting the biosorption process were observed. To describe the experimental equilibrium data, Langmuir and Freundlich isotherms models were applied. The biosorption potential of $N$. oculata biomass for $\mathrm{Cd}(\mathrm{II})$ ions was found to be $232.55 \mathrm{mg} / \mathrm{g}$. The calculated thermodynamic parameters $\left(\Delta G^{\circ}, \Delta H^{\circ}\right.$ and $\Delta S^{\circ}$ ) showed that the biosorption of Cd(II) ions onto $N$. oculata was feasible, spontaneous and exothermic at 298-323 K. Evaluation of experimental data in terms of biosorption kinetics showed that the biosorption of Cd(II) by $N$. oculata well followed pseudo-second-order kinetics. The FTIR spectra indicated that the functional groups predominantly involved in the biosorption were - $\mathrm{OH}, \mathrm{COO}-,-\mathrm{CH}$ and phosphate groups. The XRD pattern of the biosorbent showed a change in crystallinity of $N$. oculata biomass after the biosorption. It was concluded that $N$. oculata can be used as an effective, low-cost and environmentally friendly biosorbent for the removal of $\mathrm{Cd}(\mathrm{II})$ from aqueous solution.
\end{abstract}

Keywords Biosorption $\cdot$ Cadmium(II) $\cdot$ FTIR $\cdot$ Isotherms $\cdot$ Kinetics $\cdot$ Nannochloropsis oculata $\cdot$ XRD

\section{Introduction}

Globally, heavy metal pollution has become a major issue because the heavy metal content in drinking waters and wastewaters often exceeds the permissible standards. Battery manufacturing, metal plating, fertilizer industry, pigment dye stuff, mining operations and textile release heavy metals to environment via their waste effluents (Volesky 1990; Unlu and Ersoz 2006). Cadmium is one of the most toxic, non-biodegradable heavy metals and accumulated by absorption into living organisms (Victor et al. 2007). Cadmium toxicity effects include renal dysfunction, hypertension, hepatic injury, lung damage, anemia and teratogenic effects (Yu et al. 1999; Lodeiro et al. 2006; Kaewsarn and Yu 2001; Cheung et al. 2001). Cadmium pollution is due to

Jyothi Kaparapu

jyothikaparapu@gmail.com

1 Department of Botany, Andhra University, Visakhapatnam, Andhra Pradesh 530003, India

2 Department of Chemical Engineering, GMR Institute of Technology, Rajam, Srikakulam District, Andhra Pradesh 532127, India metal plating, metallurgic alloying, ceramics, textile printing industry, photograph development, electroplating, alkaline battery manufacturing industries (Kadirvelu et al. 2001; Zhu et al. 2007). Therefore, cadmium level in wastewater, drinking water and water used for agriculture should be limited to the maximum permissible concentration $(0.01 \mathrm{mg} / \mathrm{L})$ (WPCRT 2004). The usual methods for the removal of heavy metal ions including cadmium from aqueous solutions can be stated as chemical precipitation, ion exchange, solvent extraction, phytoextraction, ultrafiltration, reverse osmosis, electrodialysis and adsorption (Patterson 1985; Bhattacharya and Mandal 2006). However, technical or economic constraints limit sometimes the feasibility of such processes.

Biosorption process is emerging as one of the attractive technologies to remove heavy metals from aqueous solution. Biomasses such as bacteria (Iyer et al. 2005), yeast (Padmavathi et al. 2003), fungi (Goksungur et al. 2005; Anayurt et al. 2009) and algae (Gupta and Rastogi 2008a, b; Gupta and Rastogi 2009) were investigated as biosorbent for the removal of heavy metals. The major advantages of the biosorption technology by the use of inexpensive, naturally abundant algae are its effectiveness in reducing the concentration of colored organic compounds and toxic chemicals 
with an unpleasant smell (Holan et al. 1993; El-Sikaily et al. 2007). In algae, the biosorption has mainly been attributed to the cell wall structure containing functional groups such as amino, hydroxyl, carboxyl and sulfate, which can act as binding sites for metals via both electrostatic attraction and complexation (Hamdy 2000). Marine algae because of their cheap availability in both fresh and saltwater, relatively high surface area and high binding affinity have been found to be potentially suitable biosorbents (Hamdy 2000). It has been demonstrated that algae biosorbent might be effective in dead cells form. The easier cultivation of microalgae, its higher production yield, higher performance and efficiency because of higher specific biosorption area make microalgae more promising than macroalgae.

Different species of algal biomasses (brown, green and red) have been used for the removal of heavy metals from aqueous solution (Xin Sheng et al. 2004; Kumar et al. 2006; Schmitt et al. 2001). However, there is no extensive study on the biosorption of $\mathrm{Cd}(\mathrm{II})$ using $N$. oculata, an unicellular green microalgae. An attempt was made by choosing $N$. oculata in this study due to its renewable and cost-effective nature. The present study focused on the biosorption behavior of Nannochloropsis biomass for the removal of $\mathrm{Cd}(\mathrm{II})$ ions from aqueous solution. Experimental parameters affecting the biosorption process such as $\mathrm{pH}$, contact time, biomass dosage and temperature were evaluated. The equilibrium biosorption data were evaluated by Langmuir and Freundlich isotherm models. Bioadsorbent was characterised by FTIR and XRD studies. The biosorption mechanism was also investigated in terms of thermodynamics and kinetics.

\section{Experimental procedures}

\section{Biomass preparation}

The microalga $N$. oculata was collected from the Central Marine Fisheries Research Institute (CMFRI), Visakhapatnam. Nannochloropsis oculata was (4 million/mL) rinsed with distilled water twice, filtered by vacuum filtration and resuspended in distilled water. Sodium alginate (5\%) solution was prepared with equal quantities of algal solution and alginate solution at room temperature. This uniform mixture of algae and sodium alginate solution $(2.5 \%)$ was pumped through the peristaltic pump into the $0.5 \mathrm{M} \mathrm{CaCl}_{2}$ $2 \mathrm{H}_{2} \mathrm{O}$ solution. The beads ( 2 million $/ \mathrm{mL}$ ) were stored at $4{ }^{\circ} \mathrm{C}$ overnight for curing with $0.25 \mathrm{M} \mathrm{CaCl}_{2} 2 \mathrm{H}_{2} \mathrm{O}$ solution and washed with distilled water to avoid excess $\mathrm{CaCl}_{2} 2 \mathrm{H}_{2} \mathrm{O}$. These beads were used for equilibrium studies. Each $10 \mathrm{~mL}$ of beads contained $0.0191 \mathrm{~g}$ of dry N. oculata biomass, and this value was used for further calculation.

\section{Reagents and equipments}

All chemicals used in this work were of analytical reagent grade and were used without further purification. A PerkinElmer A Analyst 700 flame atomic absorption spectrometer (AAS) with deuterium background corrector was used. All measurements were carried out in an air acetylene flame.

\section{Preparation of adsorbate solutions}

Cadmium chloride solution was prepared by dissolving $3.6178 \mathrm{~g}$ of cadmium chloride salt in 1000-mL standard volumetric flask with deionized water. The primary stock solution thus had about $2222 \mathrm{ppm}$ of $\mathrm{Cd}(\mathrm{II})$ in solution. From the stock solutions, experimental test solutions were prepared by diluting the primary stock solution with demineralized water. $\mathrm{pH}$ was maintained at $2-5$ by addition of approximate amount of $0.1 \mathrm{~N} \mathrm{HCl}$.

\section{Batch biosorption procedure}

Biosorption experiments were carried out at the desired $\mathrm{pH}$ value, contact time and biomass dosage level using the necessary biomass in a 250-mL stoppered conical flask containing $50 \mathrm{~mL}$ of test solution. Initial solutions with different concentrations of $\mathrm{Cd}(\mathrm{II})$ were prepared by proper dilution from stock $1000 \mathrm{mg} / \mathrm{L} \mathrm{Cd}(\mathrm{II})$ standards. Sodium phosphate buffer $(0.1 \mathrm{~mol} / \mathrm{L})$ was prepared by adding an appropriate amount of phosphoric acid to sodium dihydrogen phosphate solution to result in a solution of $\mathrm{pH} 2$. Ammonium acetate buffers $(0.1 \mathrm{~mol} / \mathrm{L})$ were prepared by adding an appropriate amount of acetic acid to ammonium acetate solutions to result in solutions of $\mathrm{pH} 4-6$. Ammonium chloride buffer solutions $(0.1 \mathrm{~mol} / \mathrm{L})$ were prepared by adding an appropriate amount of ammonia to ammonium chloride solution to result in solutions of $\mathrm{pH} 8$. Necessary amount of the biomass was then added, and contents in the flask were shaken for the desired contact time in an electrically thermostatic reciprocating shaker at $200 \mathrm{rpm}$. The time required for reaching the equilibrium condition was estimated by drawing samples at regular intervals of time till equilibrium was reached. The contents of the flask were filtered through filter paper, and the filtrate was analyzed for metal concentration by using flame AAS. The percent biosorption of metal ion was calculated as follows:

Biosorption $(\%)=\left(C_{O}-C_{T}\right) / C_{O} \times 100$,

where $C_{O}$ and $C_{T}$ are the initial and final metal ion concentrations, respectively. Biosorption experiments for the effect of $\mathrm{pH}$ were conducted by using a solution having $100 \mathrm{mg} / \mathrm{L}$ of $\mathrm{Cd}(\mathrm{II})$ concentration with a biomass dosage of $10 \mathrm{~g} / \mathrm{L}$. 


\section{FTIR studies}

The powdered biomass before and after adsorption was air-dried, and the moisture was removed completely at $60{ }^{\circ} \mathrm{C}$ in a humidity control oven. The powder was analyzed by Fourier-transform infrared spectrophotometer (FTIR) by potassium bromide ( $\mathrm{KBr}$ ) pellet method in the wave number range of $400.00-4000.00 \mathrm{~cm}^{-1}$ (PerkinElmer No. 72425).

\section{X-ray diffraction analysis}

The XRD of each biomass powder sample was obtained using XRD-6000 Shimadzu, Japan Model. The diffracted $\mathrm{X}$-ray intensities were recorded as a function of $2 \theta$, at a scan speed of $1.2 \% \mathrm{~min}$, and pattern was recorded from $10^{\circ}$ to $70^{\circ}$.

\section{Results and discussion}

\section{FTIR analysis}

The FTIR spectra of unloaded biomass and Cd(II)-loaded biomass were taken (Fig. 1) to obtain information on the nature of possible interactions between the functional groups of $N$. oculata and the metal ions. The broad and strong band at $3523.13-3542.42 \mathrm{~cm}^{-1}$ may be due to the $\mathrm{N}-\mathrm{H}$ stretching vibration. The broad and strong band from 3201.01 to $3494.20 \mathrm{~cm}^{-1}$ may be due to the stretching vibration of $\mathrm{O}-\mathrm{H}$. The band peaks at $3108.42,3116.14$, $3129.64,3139.28,3151.82,3174,3181.72 \mathrm{~cm}^{-1}$ are assigned to $-\mathrm{CH}$ stretching on the biomass surface. Some bands in the fingerprint region 407.06 and $484.15 \mathrm{~cm}^{-1}$
Fig. 1 FT-IR spectrum a Cd(II)loaded algal biomass and, $\mathbf{b}$ unloaded algal biomass

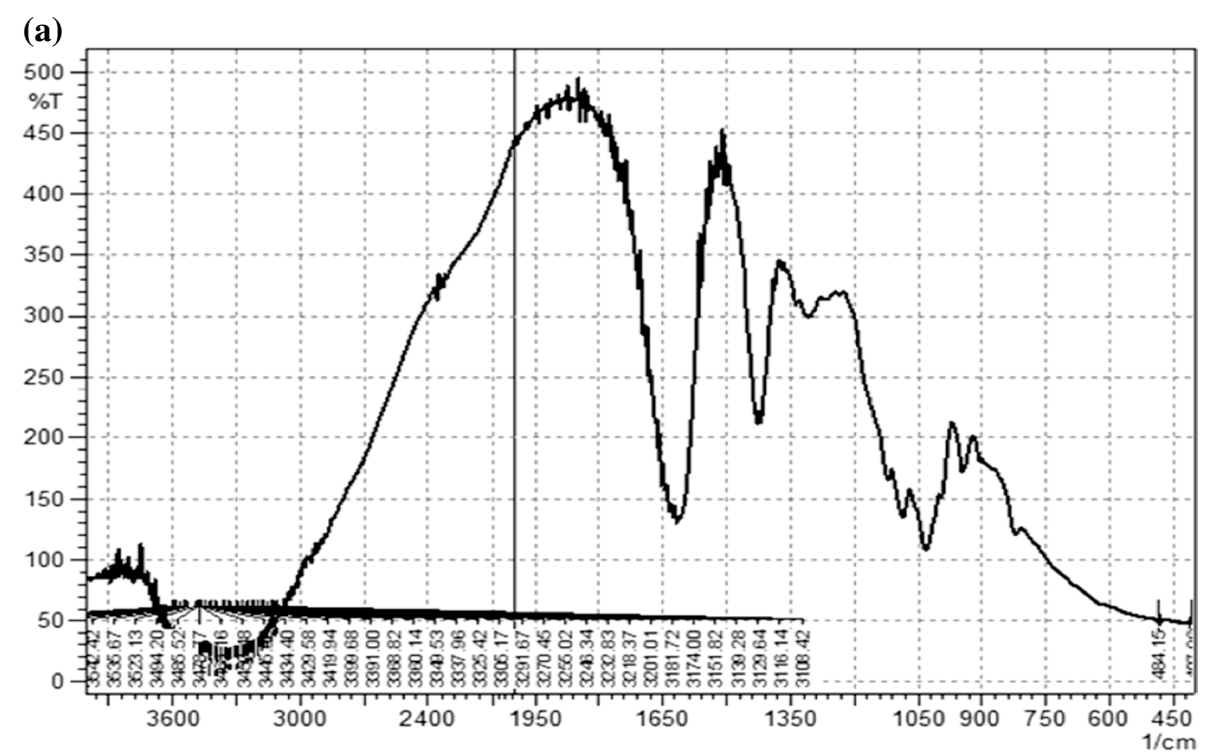

(b)

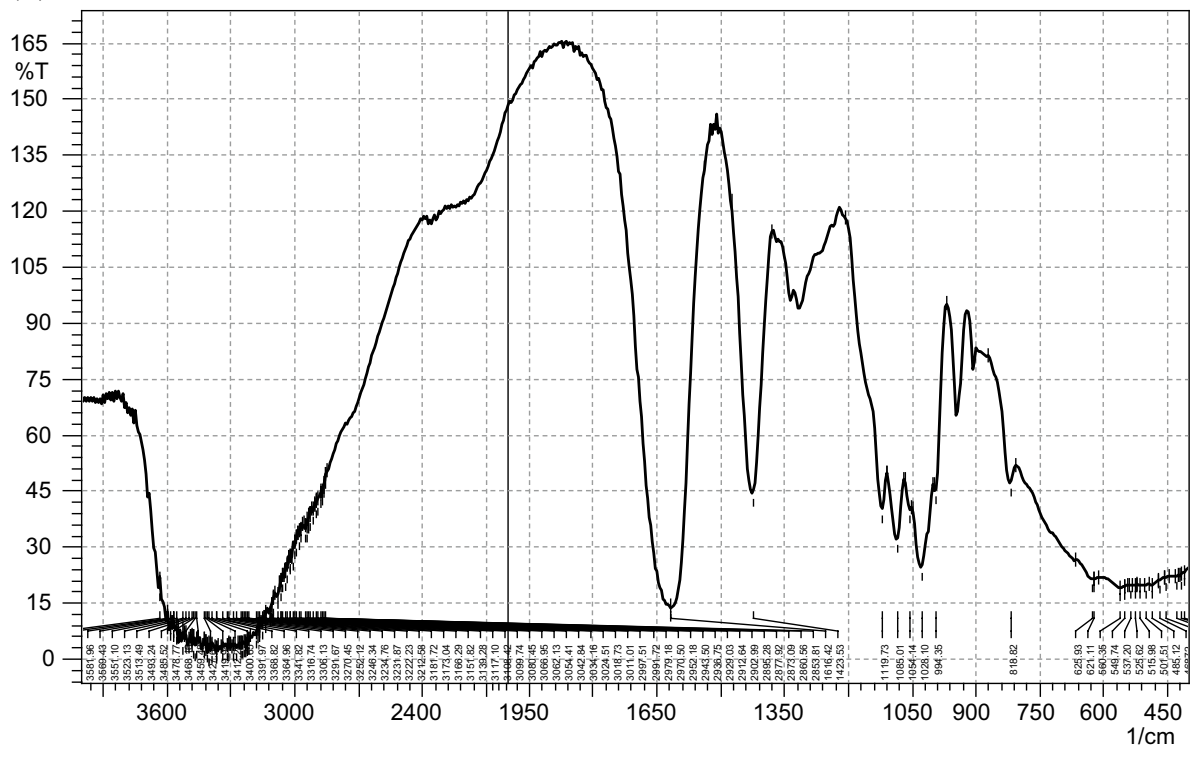


could be attributed to the phosphate groups. The significant changes in the wave numbers of these specific peaks suggested that amido, hydroxyl and phosphate groups could be involved in the biosorption of Cd(II) onto $N$. oculata. The similar results were reported for the biosorption of different heavy metals on various species of algae (Xin Sheng et al. 2004; Murphy et al. 2007).

\section{X-ray diffraction}

XRD patterns of microalgae $N$. oculata before and after biosorption are depicted in Fig. 2, and they indicated poor crystallinity of pure biomass. Furthermore, the shift in $2 \theta$ and $d$ spacing values was observed in $\mathrm{Cd}(\mathrm{II})$-loaded biomass. From these observations, it could be concluded that there was a change in the crystallinity of biomass $N$. oculata after the biosorption.

\section{Effect of $\mathrm{pH}$}

The $\mathrm{pH}$ plays an important role in the biosorption process of heavy metal ions from aqueous solutions. Algal biomasses contain high content of carboxyl groups from mannuronic and glucuronic acids on the cell wall polysaccharides, which suggests that the biosorption process could be affected by $\mathrm{pH}$ changes in the solution. To examine the effect of $\mathrm{pH}$ on the cadmium ions removal, several experiments were performed at different $\mathrm{pH}$ ranges from 2 to 5 as shown in Fig. 3 . The biosorption efficiency was obtained as $46 \%, 25 \%$ and $18 \%$ at $\mathrm{pH} 5,3$ and 2 . All the biosorption experiments were carried out at $\mathrm{pH} 5$ because the maximum efficiency was
Fig. 2 XRD pattern of $\mathbf{a}$ untreated and $\mathbf{b}$ treated with $\mathrm{Cd}(\mathrm{II}) \mathrm{N}$. oculata (a)

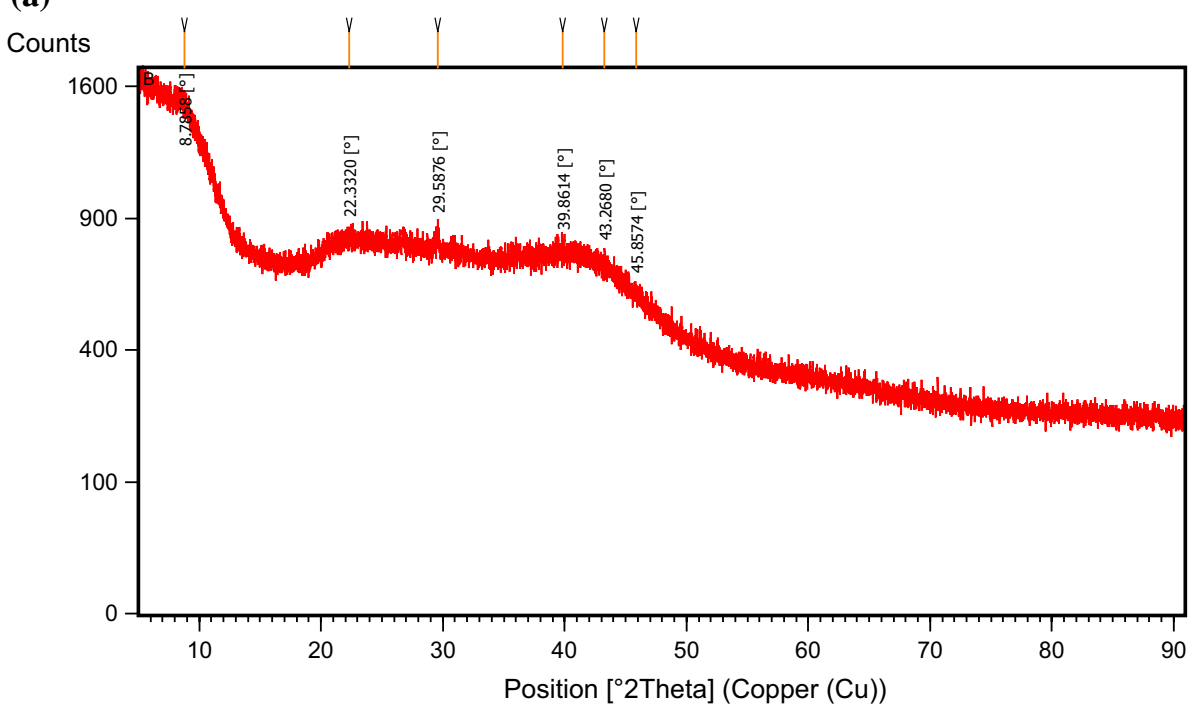

(b)

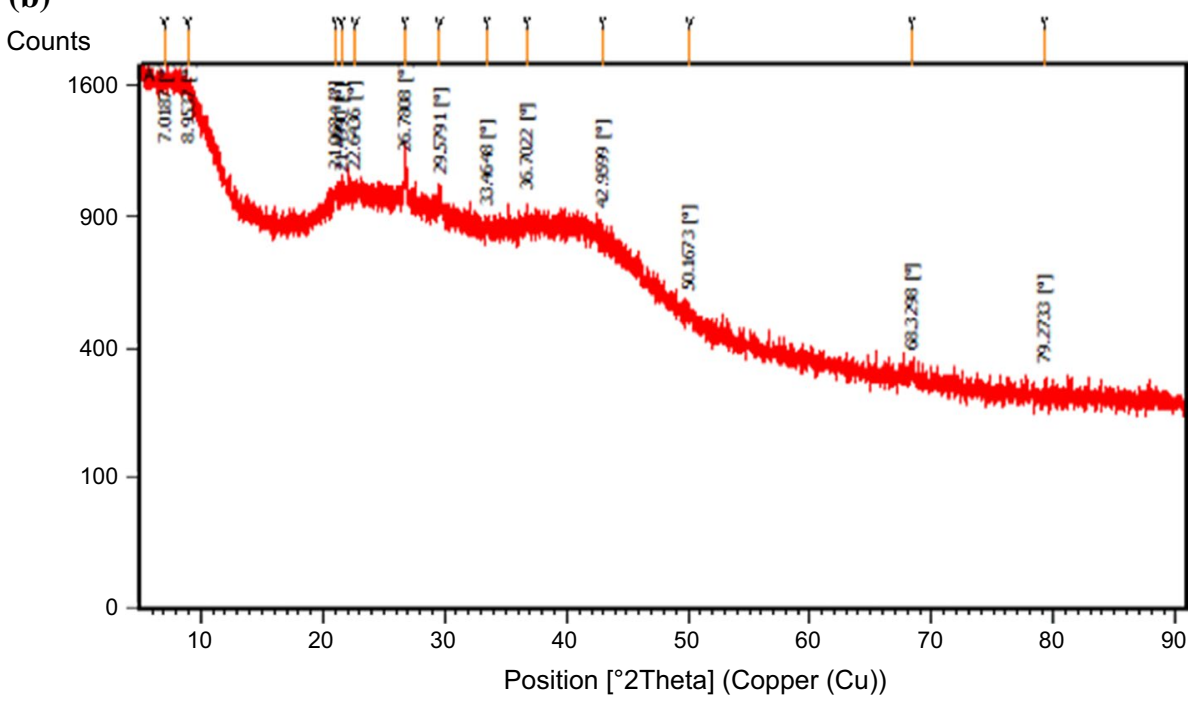




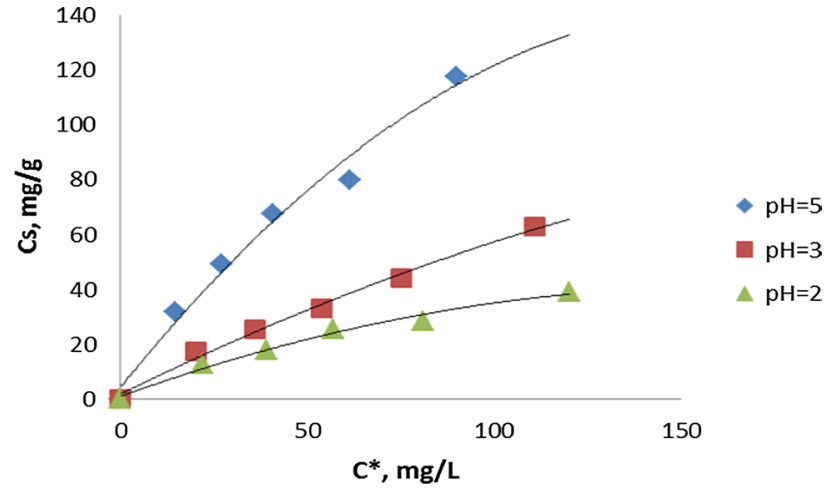

Fig. 3 Effect of $\mathrm{pH}$ on equilibrium distribution of cadmium metal ion $(298 \mathrm{~K} ; 0.091 \mathrm{~g} / 50 \mathrm{~mL})$

obtained as $46 \%$ at that $\mathrm{pH}$ value. At higher $\mathrm{pH}$ values, the biosorption yield for $\mathrm{Cd}(\mathrm{II})$ was dramatically decreased. At $\mathrm{pH}$ range 2-4, the poor biosorption of $\mathrm{Cd}(\mathrm{II})$ could be due to competition with the $\mathrm{H}^{+}$ions for metal binding sites on the algal cell. With increase in $\mathrm{pH}$, the biosorption of the $\mathrm{Cd}(\mathrm{II})$ with positive charge reached a maximum. The decrease in the biosorption efficiency at higher $\mathrm{pH}(6-8)$ values may be attributed to the formation of anionic hydroxide complexes and their competition with the active sites (Kumar et al. 2006; Rao et al. 2005).

\section{Effect of biomass dosage}

The effect of biomass dosage on the biosorption of Cd(II) ions was studied using different biomass dosages of $0.0191 \mathrm{~g} / 50 \mathrm{~mL}$ and $0.392 \mathrm{~g} / 50 \mathrm{~mL}$ (Fig. 4). Results showed that the biosorption efficiency is highly dependent on the increase in biomass dosage of the solution. This is expected because the higher dose of adsorbent in the solution, the greater availability of exchangeable sites for the ions. The maximum biosorption of the metal ions was attained at about biomass dosage $0.392 \mathrm{~g} / 50 \mathrm{~mL}$ and was almost same

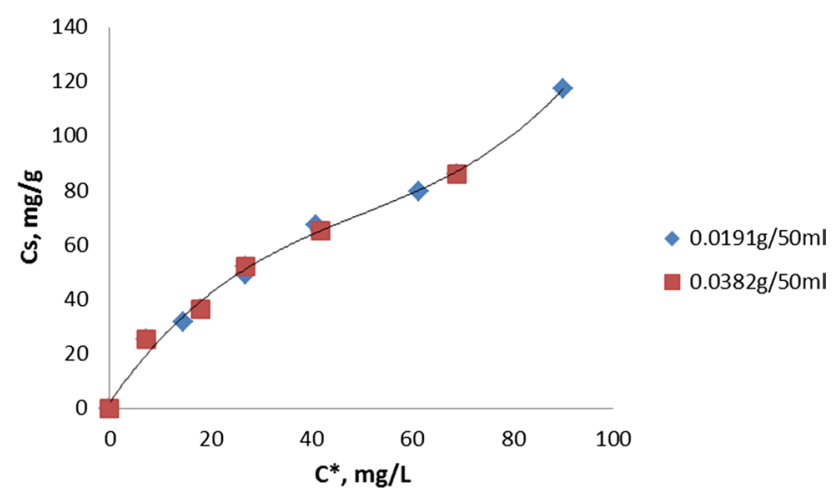

Fig. 4 Effect of biomass dosage $(\mathrm{pH}=5$; temperature $298 \mathrm{~K})$ at higher dosages. The decrease in biosorption efficiency at higher biomass concentration could be explained as a consequence of a partial aggregation of biomass, which results in a decrease in effective surface area for the biosorption (Karthikeyan et al. 2007). Therefore, the optimum biomass dosage was selected as $0.0191 \mathrm{~g} / 50 \mathrm{~mL}$ for further experiments.

\section{Effects of contact time and temperature}

The contact time was also evaluated as one of the most important factors affecting the biosorption efficiency. Figure 5 shows the biosorption efficiency of $\mathrm{Cd}(\mathrm{II})$ ions by $N$. oculata as a function of contact time and temperature. The biosorption efficiency increases with rise in contact time up to $90 \mathrm{~min}$ at $293-323 \mathrm{~K}$, and then, it is almost constant. Therefore, the optimum contact time was selected as $60 \mathrm{~min}$ for further experiments. On the other hand, the biosorption yield decreased from 45 to $27 \%$ for Cd(II) ion with increasing temperature from 298 to $323 \mathrm{~K}$ during a 90 -min contact time. This result indicated the exothermic nature of $\mathrm{Cd}(\mathrm{II})$ biosorption onto $N$. oculata. This decrease in biosorption efficiency may be attributed to many parameters: the relative
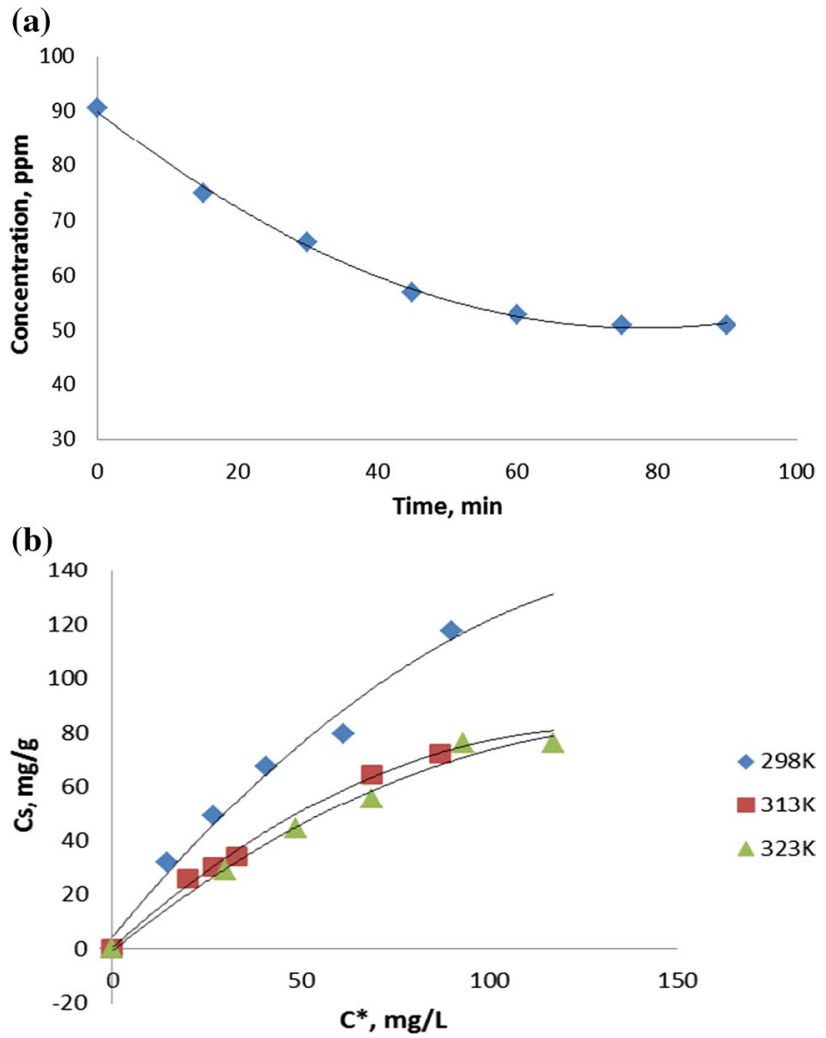

Fig. 5 Effect of contact time and temperature at $\mathrm{pH}=5$. a Variation of cadmium metal ion with time at $\mathrm{pH}=5$ and temperature $298 \mathrm{~K}$. b Variation of cadmium metal ion distribution with temperature at $\mathrm{pH}=5$ and $0.091 \mathrm{~g} / 50 \mathrm{~mL}$ 
increase in the escaping tendency of the cadmium ions from the solid phase to the bulk phase, deactivating the biosorbent surface or destructing some active sites on the biosorbent surface due to bond ruptures (Meena et al. 2005) or due to the weakness of biosorptive forces between the active sites of the sorbents and the sorbate species and also between the adjacent molecules of sorbed phase. Our results are in agreement with the thermodynamics point of view.

\section{Biosorption isotherm models}

A biosorption isotherm is characterized by certain constant values, which express the surface properties and affinity of the biosorbent and can also be used to compare the biosorptive capacities of the biosorbent for different pollutants (Dursun et al. 2005). In this study, two important sorption isotherm models were selected to fit experimental data, which are, namely, Langmuir and Freundlich isotherm models. Langmuir isotherm models the single coating layer on sorption surface. This model supposes that the sorption process takes place at a specific sorption surface. The attraction between molecules decreases as getting further from the sorption surface. Langmuir isotherm can be defined according to the following equation (Langmuir 1918):

$\frac{C_{\mathrm{e}}}{q_{\mathrm{e}}}=\frac{1}{q_{\mathrm{m}} b}+\frac{C_{\mathrm{e}}}{q_{\mathrm{m}}}$

where $q_{\mathrm{e}}$ is the equilibrium metal ion concentration on the adsorbent $(\mathrm{mg} / \mathrm{g}), C_{\mathrm{e}}$ is the equilibrium metal ion concentration in the solution $(\mathrm{mg} / \mathrm{L}), q_{\mathrm{m}}$ is the monolayer biosorption capacity of the adsorbent $(\mathrm{mg} / \mathrm{g}) . b / K_{\mathrm{L}}$ is the Langmuir biosorption constant $(\mathrm{L} / \mathrm{mg})$ relating the free energy of biosorption.

Figure 5 indicates the linear relationship between the amount (mg) of Cd(II) ions sorbed per unit mass (g) of $N$. oculata against the concentration of $\mathrm{Cd}(\mathrm{II})$ ions remaining in solution $(\mathrm{mg} / \mathrm{L})$. The correlation coefficient $\left(R^{2}\right)$ was found to be 0.992 for $\mathrm{Cd}(\mathrm{II})$ biosorption. The high $R^{2}$ values indicated that the equilibrium data fitted well to the Langmuir model. In other words, the sorption of metal ions onto $N$. oculata was taken place at the functional groups/ binding sites on the surface of the biomass which is regarded as monolayer biosorption. The $K_{\mathrm{L}}$ value was found to be $5.4 \times 10^{-3} \mathrm{~L} / \mathrm{mg}$ for $\mathrm{Cd}(\mathrm{II})$ ion (Fig. 6).

Freundlich isotherm is used for modeling the adsorption on heterogeneous surfaces. This isotherm can be explained as follows:

$q_{\mathrm{e}}=K_{f} C_{\mathrm{e}}^{\frac{1}{n_{f}}}$,

$\operatorname{In} q_{e}=\ln K_{f}+\frac{1}{n_{f}} \operatorname{In} C_{e}$,

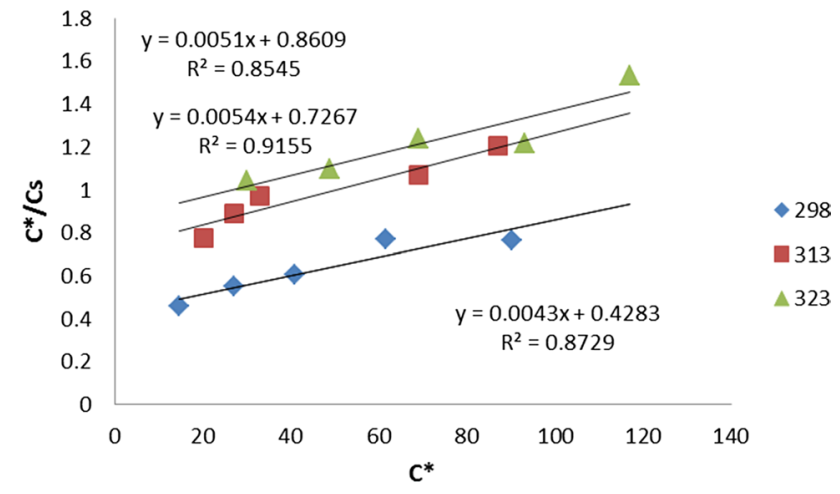

Fig. 6 Langmuir isotherm plots for biosorption of $\mathrm{Cd}(\mathrm{II})$ onto $N$. oculata biomass (biomass dosage $20 \mathrm{~g} / \mathrm{L}$; contact time $60 \mathrm{~min}$; $\mathrm{pH}$ 5; temperature $298 \mathrm{~K}$ )

where $K_{f}$ is a constant relating the biosorption capacity and $1 / n$ is an empirical parameter relating the biosorption intensity, which varies with the heterogeneity of the material (Figs. 7).

The values of $K_{f}$ and $1 / n$ were found to be 4.4 and 0.3 , respectively. The $1 / n$ values were between 0 and 1 , indicating that the biosorption of $\mathrm{Cd}(\mathrm{II})$ onto $N$. oculata biomass was favorable at studied conditions. However, compared to the $R^{2}$ values, 0.978 with that obtained from the Langmuir model, it can be remarkably noted that the Langmuir isotherm model is better fitted the equilibrium data.

\section{Biosorption kinetics}

In order to examine the controlling mechanism of the biosorption process, kinetic models are used to test the experimental data. The equilibrium data were analyzed using two simplest kinetic models, pseudo-first-order and pseudo-second-order model.

The linear form of the pseudo-first-order rate equation by Lagergren (1898) is given as

$\ln \left(q_{\mathrm{e}}-q_{t}\right)=\ln q_{\mathrm{e}}-k_{1} t$,

where $q_{t}$ and $q_{\mathrm{e}}(\mathrm{mg} / \mathrm{g})$ are the amounts of the metal ions biosorbed at equilibrium $(\mathrm{mg} / \mathrm{g})$ and $t(\mathrm{~min})$, respectively, and $k_{1}$ is the rate constant of the first-order equation $\left(\mathrm{min}^{-1}\right)$. The biosorption rate constants $\left(k_{1}\right)$ can be determined experimentally by plotting $\ln \left(q_{\mathrm{e}}-q_{t}\right)$ versus $t$ (Fig. 8).

The pseudo-second-order kinetic model fitted the experimental data which is given in the following form:

$\frac{t}{q_{t}}=\frac{1}{k_{2} q_{\mathrm{e}}^{2}}+\frac{1}{q_{\mathrm{e}}} t$,

where $k_{2}(\mathrm{~g} / \mathrm{mg} \mathrm{min})$ is the rate constant of the second-order equation, $q_{t}$ and $q_{\mathrm{e}}(\mathrm{mg} / \mathrm{g})$ are the amounts of the metal ions biosorbed at equilibrium $(\mathrm{mg} / \mathrm{g})$ and $t(\mathrm{~min})$, respectively. This model is more likely to predict kinetic behavior of 

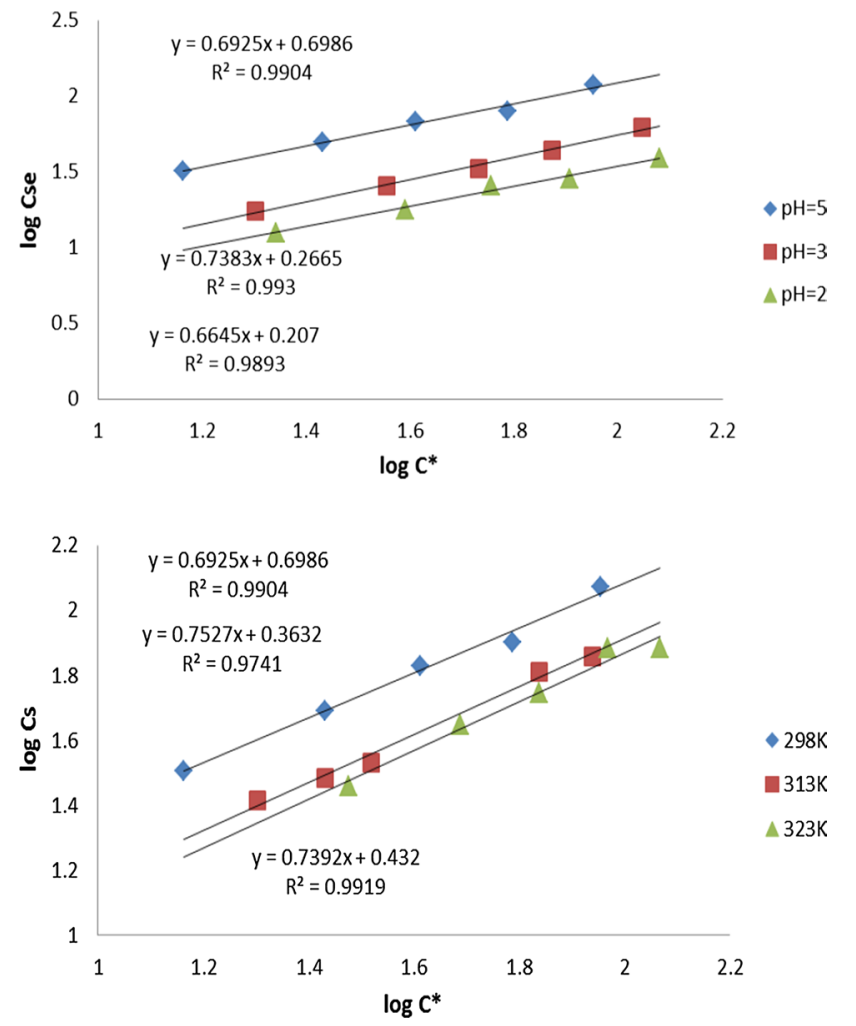

Fig. 7 Freundlich isotherms obtained for the biosorption of $\mathrm{Cd}(\mathrm{II})$ ions onto N. oculata biomass using Eq. (3)

biosorption with chemical sorption being the rate-controlling step (Dubinin and Radushkevich 1947). The linear plots of $t / q t$ versus $t$ for the pseudo-second-order model for the biosorption of $\mathrm{Cd}(\mathrm{II})$ ions onto the alga biomass at $293 \mathrm{~K}$ was shown in Fig. 9. These results suggest that this model successfully describes the kinetics of the biosorption of $\mathrm{Cd}(\mathrm{II})$ ions onto $N$. oculata. This conclusion is in agreement with that obtained by other authors (Martinez et al. 2006; Schmitt et al. 2001). The rate constants $\left(k_{2}\right)$, the $R_{2}$ and the $q_{\mathrm{e}}$ values are given in Table 1. It is clear from these results that the $R_{2}$ values are very high.

\section{Biosorption thermodynamics}

Thermodynamic parameters including the change in free energy $\left(\Delta G^{\circ}\right)$, enthalpy $\left(\Delta H^{\circ}\right)$ and entropy $\left(\Delta S^{\circ}\right)$ were used to describe thermodynamic behavior (Choi et al. 2009) of the

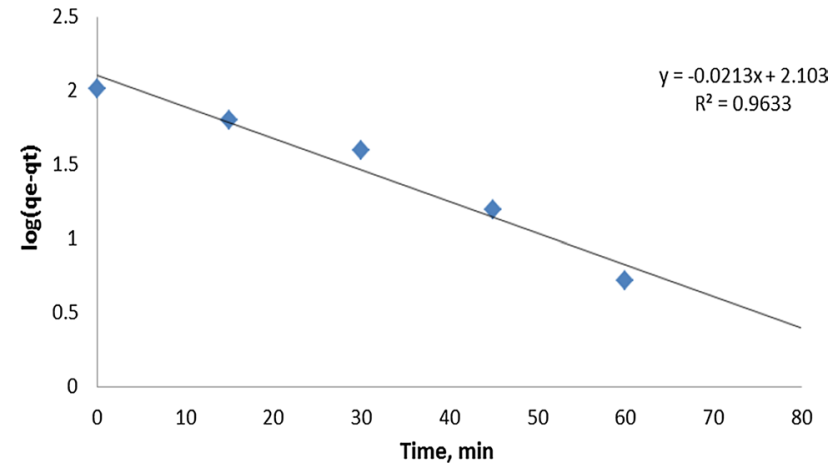

Fig. 8 Pseudo-first-order kinetic plot for biosorption of $\mathrm{Cd}(\mathrm{II})$ at $298 \mathrm{~K}$ and $\mathrm{pH} 5$

biosorption of $\mathrm{Cd}(\mathrm{II})$ ions onto $\mathrm{N}$. oculata. These parameters were calculated from the following equations:

$\Delta G^{\circ}=-R T \ln K c$,

where $R$ is the universal gas constant $(8.314 \mathrm{~J} / \mathrm{mol} \mathrm{K}), T$ is temperature $(\mathrm{K})$ and $K\left(q \mathrm{e} / C_{\mathrm{e}}\right)$ is the distribution coefficient (Dubinin and Radushkevich 1947). By considering the following equation, the enthalpy $\left(\Delta H^{\circ}\right)$ and entropy $\left(\Delta S^{\circ}\right)$ of biosorption were estimated from the slope and intercept of the plot of $\ln K$ versus 1/T (Fig. 10).

$K_{C}=\frac{C_{S}}{C_{\mathrm{e}}}$

$\log \left(\frac{C_{S}}{C_{\mathrm{e}}}\right)=-\frac{\Delta H^{\circ}}{2.303 R T}+\frac{\Delta S^{\circ}}{R}$

The free energy change $\left(\Delta G^{\circ}\right)$ was calculated to be $-45.94,-44.02$ and $\mathrm{kJ} / \mathrm{mol}$ for the biosorption of $\mathrm{Cd}(\mathrm{II})$ at 298,313 and $323 \mathrm{~K}$, respectively. The negative $\Delta G^{\circ}$ values indicated thermodynamically feasible and spontaneous nature of the biosorption. The decrease in $\Delta G^{\circ}$ values with increase in temperature shows a decrease in feasibility of biosorption at higher temperatures. The enthalpy of biosorption $\left(\Delta H^{\circ}\right)$ was found to be $-20.15 \mathrm{~kJ} / \mathrm{mol}$. The negative $\Delta H^{\circ}$ is indicator of exothermic nature of the biosorption, and also its magnitude gives information on the type of biosorption, which can be either physical or chemical. The enthalpy value $(-31.8 \mathrm{~kJ} / \mathrm{mol})$ indicated that the biosorption process of Cd(II) ions onto $N$. oculata biomass proceeded chemically
Table 1 Langmuir and Freundlich isotherm model parameters for $\mathrm{Cd}(\mathrm{II})$ biosorption on $N$. oculata

\begin{tabular}{|c|c|c|c|c|c|c|c|}
\hline \multirow[t]{2}{*}{ Temp. $\left({ }^{\circ} \mathrm{K}\right)$} & \multicolumn{4}{|c|}{ Langmuir constants } & \multicolumn{3}{|c|}{ Freundlich constants } \\
\hline & $\mathrm{pH}$ & $q_{m}\left(\mathrm{mg} \mathrm{g}^{-1}\right)$ & $b\left(\mathrm{~L} \mathrm{mmol}^{-1}\right)$ & $R^{2}$ & $K_{F}$ & $n_{f}$ & $R^{2}$ \\
\hline 298 & 5 & 232.5581 & 0.01004 & 0.8545 & 0.200170466 & 1.444043321 & 0.9904 \\
\hline 313 & 5 & 185.1852 & 0.007431 & 0.9155 & 0.36982818 & 1.328550551 & 0.9741 \\
\hline 323 & 5 & 196.0784 & 0.005924 & 0.8729 & 0.433311285 & 1.352813853 & 0.9919 \\
\hline
\end{tabular}




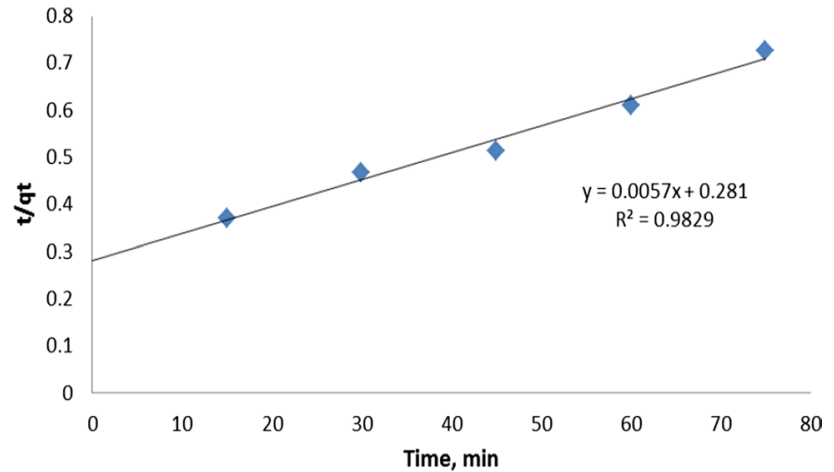

Fig. 9 Pseudo-second-order kinetic for biosorption Cd(II) $\mathrm{pH} 5$

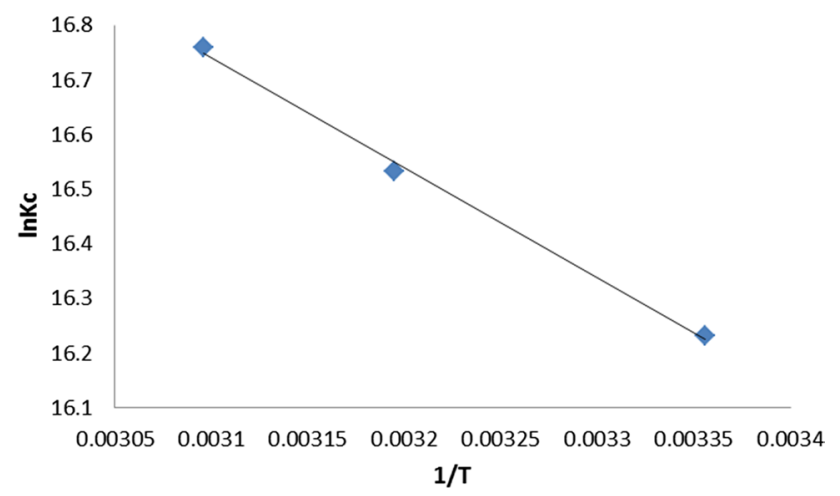

Fig. 10 Plot of $\ln K c$ versus $1 / T$ for the estimation of thermodynamic parameters

because it falls into the $20.9-418.4 \mathrm{~kJ} / \mathrm{mol}$ (Freundlich 1906). The $\Delta S^{\circ}$ parameter was found to be $22.8 \mathrm{~J} / \mathrm{mol} \mathrm{K}$ for Cd(II) biosorption. The negative $\Delta S^{\circ}$ value suggests a decrease in the randomness at the solid/solution interface during the biosorption process.

\section{Conclusions}

This study focused on the biosorption of $\mathrm{Cd}(\mathrm{II})$ ions onto algal biomass ( $N$. oculata) from aqueous solution, and the operating parameters, $\mathrm{pH}$ of solution, biomass dosage, contact time and temperature on the biosorption efficiency of $\mathrm{Cd}(\mathrm{II})$ were studied. Biosorption equilibrium was better described by the Freundlich isotherm model than the Langmuir isotherm. The monolayer biosorption capacity of $N$. oculata for Cd(II) was found to be $232.55 \mathrm{mg} / \mathrm{g}$ ions. Kinetic examination of the equilibrium data showed that the biosorption of Cd(II) ions onto Nannochloropsis followed well the pseudo-second-order kinetic model. The thermodynamic calculations indicated the feasibility, exothermic and spontaneous nature of the biosorption process at 298-323 K. Based on the results, it can be concluded that the $N$. oculata is an effective and alternative biomass for the removal of $\mathrm{Cd}$ (II) ions from aqueous solution.

Acknowledgements One of the authors Jyothi Kaparapu gratefully acknowledges financial assistance from the UGC, New Delhi (Post-Doctoral Fellowship for women) No. F.151/2014-15/ PDFWM-2014-15-AND-26595(SAII).

Open Access This article is distributed under the terms of the Creative Commons Attribution 4.0 International License (http://creativeco mmons.org/licenses/by/4.0/), which permits unrestricted use, distribution, and reproduction in any medium, provided you give appropriate credit to the original author(s) and the source, provide a link to the Creative Commons license, and indicate if changes were made.

\section{References}

Anayurt RA, Sari A, Tuzen M (2009) Equilibrium, thermodynamic and kinetic studies on biosorption of $\mathrm{Pb}$ (II) and $\mathrm{Cd}$ (II) from aqueous solution by macrofungus (Lactarius scrobiculatus) biomass. Chem Eng J 151:255-261

Bhattacharya AKSN, Mandal DS (2006) Adsorption of Zn(II) from aqueous solution by using different adsorbents. Chem Eng J 123:43-51

Cheung CW, Porter JF, Mckay G (2001) Sorption kinetic analysis for the removal of cadmium ions from effluents using bone char. Water Res 35:605-612

Choi HD, Jung WS, Cho JM, Ryu BG, Yang JS, Baek K (2009) Adsorption of $\mathrm{Cr}(\mathrm{VI})$ onto cationic surfactant-modified activated carbon. J Hazard Mater 166:642-646

Dubinin MM, Radushkevich LV (1947) Equation of the Characteristic curve of activated charcoal. Chemisches Zentralblatt 1:875-889

Dursun G, Cicek H, Dursun AY (2005) Adsorption of phenol from aqueous solution by using carbonized beet pulp. J Hazard Mater 125:175-182

El-Sikaily A, El-Nemr A, Khaled A, Abdelwehab O (2007) Removal of toxic chromium from wastewater using green alga Ulva lactuca and its activated carbon. J Hazard Mater 148:216-228

Freundlich HMF (1906) Uber die adsorption in losungen. Zeitschrift fur Physikalische Chemie (Leipzig). A 57:385-470

Goksungur Y, Uren S, Guvenc U (2005) Biosorption of cadmium and lead ions by ethanol treated waste baker's yeast biomass. Bioresour Technol 96(1):103-109

Gupta VK, Rastogi A (2008a) Biosorption of lead(II) from aqueous solutions by non-living algal biomass Oedogonium sp. and Nostoc sp.—a comparative study. Colloids Surf B Biointerface 64:170-178

Gupta VK, Rastogi A (2008b) Biosorption of lead from aqueoussolutions by green algae Spirogyra species: kinetics and equilibrium studies. J Hazard Mater 152:407-414

Gupta VK, Rastogi A (2009) Biosorption of hexavalent chromium by raw and acid-treated green alga Oedogonium hatei from aqueous solutions. J Hazard Mater 163:396-402

Hamdy AA (2000) Removal of $\mathrm{Pb}^{2+}$ by biomass of marine algae. Curr Microbiol 41:239-245

Holan ZR, Volesky B, Prasetyo I (1993) Biosorption of cadmium by biomass of marine algae. Biotechnol Bioeng 41:819-825

Iyer A, Mody K, Jha B (2005) Biosorption of heavy metals by a marine bacterium. Mar Pollut Bull 50(3):340-343 
Kadirvelu K, Thamaraiselvi K, Namasivayam C (2001) Removal of heavy metals from industrial wastewaters by adsorption onto activated carbon prepared from an agricultural solid waste. Bioresour Technol 76:63-65

Kaewsarn P, Yu Q (2001) Cadmium(II) removal from aqueous solutions by pretreated biomass of marine alga Padina sp. Environ Pollut 112:209-213

Karthikeyan S, Balasubramanian R, Iyer CSP (2007) Evaluation of the marine algae Ulva fasciata and Sargassum sp. for the biosorption of $\mathrm{Cu}$ (II) from aqueous solutions. Biores Technol 98:452-455

Kumar YP, King P, Prasad VSRK (2006) Removal of copper from aqueous solution using Ulva fasciata sp. A marine green algae. J Hazard Mater 137:367-373

Lagergren S (1898) Zur theorie der sogenannten adsorption gelöster stoffe, K. Sven. Vetenskapsakad. Handl. 24: 1-39

Langmuir I (1918) The adsorption of gases on plane surfaces of glass, mica and platinum. J Am Chem Soc 40:1361-1403

Lodeiro P, Barriada JL, Herrero R, Sastre de Vicente ME (2006) The marine macroalga Cystoseira baccata as biosorbent for cadmium(II) and lead(II) removal: kinetic and equilibrium studies. Environ Pollut 142:264-273

Martinez M, Miralles N, Hidalgo S, Fiol N, Villaescusa I, Poch J (2006) Removal Of Lead (II) and cadmium (II) from aqueous solutions using grape stalk waste. J Hazard Mater B 133:203-211

Meena AK, Mishra GK, Rai PK, Rajagopal C, Nagar PN (2005) Removal of heavy metal ions from aqueous solutions using carbon aerogel as an adsorbent. J Hazard Mater 122:161-170

Murphy V, Hughes H, McLoughlin P (2007) Cu(II) binding by dried biomass of red, green and brown macroalgae. Water Res 41:731-740

Padmavathy V, Vasudevan P, Dhingra SC (2003) Biosorption of nickel(II) ions on Baker's yeast. Process Biochem 38(10):1389-1395

Patterson JW (1985) Industrial wastewater treatment technology, 2nd edn. Butterworth-Heinemann, London
Rao PS, Kalyani S, Suresh Reddy KVN, Krishnaiah A (2005) Comparison of biosorption of nickel(II) and copper(II) ions from aqueous solution by sphaeroplea algae and acid treated sphaeroplea algae. Sep Sci Technol 40:3149-3165

Schmitt D, Mue Ller A, Csoe Goe Z, Frimmel FH, Posten C (2001) The adsorption kinetics of metal ions onto different microalgae and siliceous earth. Water Res 35:779-785

Unlu N, Ersoz M (2006) Adsorption characteristics of heavy metal ions onto a low cost biopolymeric sorbent from aqueous solutions. $\mathrm{J}$ Hazard Mater 136:272-280

Victor JPV, Cidalia MSB, Rui ARB (2007) Chromium and zinc uptake by algae Gelidium and agar extraction agal waste: kinetics and equilibrium. J Hazard Mater 149:643-649

Volesky B (1990) Removal and recovery of heavy metals by biosorption. CRC Press, Boca Raton, pp 3-43

WPCRT (2004) Water pollution control regulation of Turkish Authorities. Turkish Official Gazette, Turkey, p 25687

Xin Sheng P, Ting YP, Paul Chen J, Hong L (2004) Sorption of lead, copper, cadmium, zinc, and nickel by marine algal biomass: characterization of biosorptive capacity and investigation of mechanisms. J Colloid Interface Sci 275:131-141

Yu Q, Matheickal JT, Yin P, Kaewsarn P (1999) Heavy metal uptake capacities of common marine macroalgal biomass. Water Res 33:1534-1537

Zhu C, Luan Z, Shan X (2007) Removal of cadmium from aqueous solution by adsorption on granular red mud (GRM). Sep Purif Technol 57:161-169

Publisher's Note Springer Nature remains neutral with regard to jurisdictional claims in published maps and institutional affiliations. 